\title{
Algae as indicator to assess trophic status in Duhok Lake, Kurdistan region of Iraq
}

\author{
Janan Jabbar Toma \\ Environmental Sciences Department- College of Science- University of Salahaddin- Erbil, Iraq
}

\begin{abstract}
In present study, algal groups which are used as indicator to trophic and pollution status of Duhok lake. Data that applied for Nygaard's indices, dominant genus scores, Chlorophyll a and Palmer's index of pollution, were collected from only previous study happened for Duhok lake during 2002. Total 250 algal taxa which have classified into 6 taxonomic groups were identified. Diatoms members constituted the dominant phytoplankton group in terms of species number, out of 115 identified taxa of diatoms; only seven centric taxa were identified. The Ny gaard's compound index value and composition of phy toplankton indicate that the trophic state of Duhok Dam Lake was eutrophic. The trophic state indices of Myxophycean and Chlorophycean in this survey is indicating Eutrophic nature of lake water and the trophic state indices of Diatoms and Euglenophycean indicate oligotrophic nature of water. As a result of dominant genus scores was (5.7), the lake has a mesotrophic-eutrophic character according to trophic level, in addition, the water quality of Lake Duhok was moderate and moderate

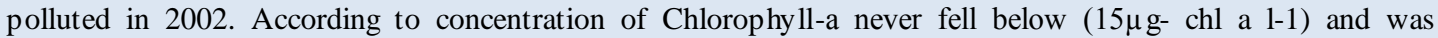
eutrophic status. The most pollution tolerant species of Euglena, Phacus, Phormidium, Oscillatoria, Scenedesmus, Pandorina, Chlamydomonas, Closterium and Nitzschia identified in lake. These genus are tolerant to pollution depending to Palmer (1969). This communities of algae indicate to that reservoir was highly polluted by organic matter. The total score of Algal genus pollution index was 37 in Duhok lake that indicates to confirm high organic pollution and was eutrophic state.
\end{abstract}

\section{Introduction}

Algae form the main source of food and oxygen for consumer organis ms in water habitats, directly affect primary production by forming base level of food chain. And also, it is concluded that the algae have main role in assessing water contamination and clean ing waste water (Bhatt et al. 1999). Algae are one of the more important bioindicators of water quality changes due to their short life spans, speed response to contaminant and easy to determine their numbers (Plafkin et al., 1989). Various methods used to classification the lakes and determined the trophic status, the most commonly way depended on productivity by using algae related to trophic state index(Bhatt et al. 1999). Recognition of variances in the quality and quantity of plankton in lakes contributed to the origin of the trophic system of lake classification. These have been mainly related with the phytoplankton and include the use of a variety of indices and quotients. This field has been developed mainly by European researchers with, as yet, little uses to the waters of North A merica (Chandrashekar et al., 2014). The-trophic status of water bodies is an important aspect in finding out the water quality. The trophic status means to the level of production in a Lakes as calculated by many factors such as algal composition, and chlorophyll a (Chandrashekar et al., 2014). The chlorophyll-a concentration (hereafter referred to as Chl-a) is an important parameter in evaluating water quality, nutrition status and organic pollution extent, providing useful information for managing water quality

( Scherz,1972) and monitoring water pollution (Johson and Harris,1980).Palmer (1969) also demonstrated that algal assemblages may be used as indicators of clean or contaminated water, similarly My xophycean and Chlorophycean forms have been reported to reflect specific state of aquatic habitats on the basis of Nygaard's indices. The main aim of this investigation to determine the trophic status in Duhok lake depending on variation of algae and application some index to determination its quality. 
Materials and Methods

\section{Data collection}

Applied algal data for Nygaard's indices, dominant genus scores, Chlorophyll a and Palmer's index of pollution were collected from previous study for Duhok lake (Al- Nakshabandi, 2000).

\section{Study area:}

The Dohuk dam is located north of city of Duhok, Iraq (latitude: $36^{\circ} 52^{\prime} 33^{\prime \prime} \mathrm{N}$; longitude: $43^{\circ} 00^{\prime} 13^{\prime \prime} \mathrm{E}$ ). It was constructed on the Dohuk River. The built of dam was completed in 1988 with the main aim of supply water for irrigation. It is $60 \mathrm{~m}$ height and can capacity 52,000,000 m3 of water. The maximu $\mathrm{m}$ discharge of dam is $81 \mathrm{~m} 3 / \mathrm{s}$. The length of reservoir is $4 \mathrm{~km}$ and largest width is about $1.7 \mathrm{~km}$, with depths site is $60 \mathrm{~m}$ (Shekha et al., 2013) (Figure 1).

\section{Algal Indices}

Nygaard (1976) suggested five indices to evaluation the pollution by organic matter of water bodies depend on different groups of planktonic algae happening in them. These indices include Cyanophycean or Myxophycean index, Chlorophycean index, Bacillariophycean, Euglenophycean index and Compound Quotient (CQ) . All these are useful in estimation of the trophic status of a particular lake. This calculation is based on the fact that algae have the capacity to tolerance organic pollution. Cyanophycean, Euglenophycean members can tolerate contamination and categorize the water body as eutrophic. Pennate diatoms and Desmids usually inhabit oligotrophic water (Nygaard ,1976).

Ecological status of the Duhok lake estimated, depending on planktonic algae and content and the phytoplankton compound quotient (PCQ). PCQ was used to determination the ecological status of the lake. Many studies suggested the proportion of number of species of the groups existing in the phytoplankton with one another indicates the efficiency of the lake (Nygaard ,1949; Thun mark, 1945 and Hutchinson, 1967). A mong those proportions the coefficient proposed by Nygaard (Nygaard ,1949 was applied more frequently. This index is one that is best useful for explaining the trophic degree of a lake.

$$
\begin{aligned}
& \text { The Myxophycean index }=\frac{\text { number of species of myxophyceae }}{\text { number of species of desmideae }} \\
& \text { The Chlorophycean index }=\frac{\text { number of species of Chlorococcales }}{\text { number of species of desmideae }} \\
& \text { The Diatom index }=\frac{\text { number of species of centric Diatoms }}{\text { number of species of pennate Diatoms }} \text { number of species of Euglenophyta } \\
& \text { The Euglenophycean index }=\frac{\text { Myxophyceae } *+\text { Chlorococcales } *+\text { Centrales } *+\text { Euglenophyceae }}{\text { number species of Myxophyceae and Chlorococcales }} \\
& \qquad \text { PCQ }=\frac{\text { Desmidiaceae }}{}
\end{aligned}
$$

The species of the phytoplankton community is an indicators for water quality (Peerapornpisal et al, 2007). In this survey, the diversity of phytoplankton was studied and the water quality was estimated depended on the physical and chemical.

In estimating the trophic status, several things are used in terms of nutrient concentration, species composition of phytoplankton, fauna and flora quantity and quality. And the variance that may arise in determining the trophic levels of the lake among them are analyzed looking through several parameters. Trophic status brings a new approach to trophic restriction of lakes. PCQ (Nygaard, 1949)and dominant genus (Peerapornpisal et al, 2007)were used in order to determine trophy.

Because eutrophication is defined as an aquatic ecosystems response to nutrient loading, the ability to identify important factors and predict subsequent algal blooms with the use of a Chl a equation could be a key lake water management tool. Chlorophyll a concentration has been used for many years as a directly indicate of trophic state (Henderson-sellers and Markland 1988). Trophic status boundaries as defined by various boundary levels of chlorophyll a of lakes.

properties. In Table 1, list of dominance genus. 
Table 1. List of dominance genus scores (Peerapornpisal et al, 2007)

\begin{tabular}{llllll}
\hline Genus & Score & Genus & Score & Genus & Score \\
\hline Actinastrum & $\mathbf{5}$ & Dictyosphaerium & $\mathbf{7}$ & Nitzschia & $\mathbf{9}$ \\
Acanthoceras & $\mathbf{5}$ & Dimorphococcus & $\mathbf{7}$ & Oocystis & $\mathbf{6}$ \\
Amphora & $\mathbf{6}$ & Dinobryon & $\mathbf{1}$ & Oscillatoria & $\mathbf{9}$ \\
Anabaena & $\mathbf{8}$ & Encyonema & $\mathbf{6}$ & Pandorina & $\mathbf{6}$ \\
Ankistrodesmus & $\mathbf{7}$ & Epithemia & $\mathbf{6}$ & Pediastrum & $\mathbf{7}$ \\
Aphanocapsa & $\mathbf{5}$ & Euastrum & $\mathbf{3}$ & Peridiniopsis & $\mathbf{6}$ \\
Aphanothece & $\mathbf{5}$ & Eudorina & $\mathbf{6}$ & Peridinium & $\mathbf{6}$ \\
Aulacoseira & $\mathbf{6}$ & Euglena & $\mathbf{1 0}$ & Phacus & $\mathbf{8}$ \\
Bacillaria & $\mathbf{7}$ & Eunotia & $\mathbf{2}$ & Phormidium & $\mathbf{9}$ \\
Botryococcus & $\mathbf{4}$ & Fragilaria & $\mathbf{5}$ & Pinnularia & $\mathbf{5}$ \\
Centritractus & $\mathbf{4}$ & Golenkinia & $\mathbf{5}$ & Planktolyngbya & $\mathbf{7}$ \\
Ceratium & $\mathbf{4}$ & Gomphonema & $\mathbf{6}$ & Pseudanabaena & $\mathbf{7}$ \\
Chlamydomonas & $\mathbf{6}$ & Gonium & $\mathbf{6}$ & Rhizosolenia & $\mathbf{6}$ \\
Chlorella & $\mathbf{6}$ & Gymnodinium & $\mathbf{6}$ & Rhodomonas & $\mathbf{8}$ \\
Chroococcus & $\mathbf{6}$ & Gyrosigma & $\mathbf{7}$ & Rhopalodia & $\mathbf{5}$ \\
Closterium & $\mathbf{6}$ & Isthmochloron & $\mathbf{5}$ & Scenedesmus & $\mathbf{8}$ \\
Cocconeis & $\mathbf{6}$ & Kirchneriella & $\mathbf{5}$ & Staurastrum & $\mathbf{3}$ \\
Coelastrum & $\mathbf{7}$ & Melosiera & $\mathbf{5}$ & Staurodesmus & $\mathbf{3}$ \\
Cosmarium & $\mathbf{2}$ & Merismopedia & $\mathbf{9}$ & Stauroneis & $\mathbf{5}$ \\
Crucigenia & $\mathbf{7}$ & Micractinium & $\mathbf{7}$ & Strombomonas & $\mathbf{8}$ \\
Crucigeniella & $\mathbf{7}$ & Micrasterias & $\mathbf{2}$ & Surirella & $\mathbf{6}$ \\
Cryptomonas & $\mathbf{8}$ & Microcystis & $\mathbf{8}$ & Synedra & $\mathbf{6}$ \\
Cyclotella & $\mathbf{2}$ & Monoraphi dium & $\mathbf{7}$ & Tetraedron & $\mathbf{6}$ \\
Cylindrospermopsis & $\mathbf{7}$ & Navicula & $\mathbf{5}$ & Trachelomonas & $\mathbf{8}$ \\
Cymbella & $\mathbf{5}$ & Nephrocytium & $\mathbf{5}$ & Volvox & $\mathbf{6}$ \\
\hline
\end{tabular}

Palmer (1969) made the first major attempt to identify and prepare a list of genera of algae tolerance to pollution by organic. Palmer developed algal genus index for the know the rating of organic pollution of a water system. For the calculate of this index, (table 2) is taken for use. The table provides 20 algal genera most tolerant to organic pollution. (Palmer,1969) formulated the following pollution index scale for assessment of organic pollution of the water bodies (table 3). Palmer's pollution index of algal genera is taken into account for evaluation of water quality.

Table 2 :- Algal Genus Pollution Index (Palmer 1969)

\begin{tabular}{llll}
\hline Genus & Index & Genus & Index \\
\hline Anacystis & $\mathbf{1}$ & Micractinium & $\mathbf{1}$ \\
Ankistrodesmus & $\mathbf{2}$ & Navicula & $\mathbf{3}$ \\
Chlamydomonas & $\mathbf{4}$ & Nitzschia & $\mathbf{3}$ \\
Chlorella & $\mathbf{3}$ & Oscillatoria & $\mathbf{5}$ \\
Closterium & 1 & Pandorina & 1 \\
Cyclotella & 1 & Phacus & 2 \\
Euglena & 5 & Phormidium & 1 \\
Gomphonema & 1 & Scenedesmus & 4 \\
Lepocinclis & 1 & Stigeoclonium & 2 \\
Melosira & 1 & Syndra & 2 \\
\hline
\end{tabular}




\section{Table(3):- Pollution Index Scale}

\begin{tabular}{ll}
\hline Pollution index & Status of pollution \\
\hline$<15$ & Very light organic pollution \\
15 to 20 & Organic pollution \\
$>20$ & High organic pollution \\
\hline
\end{tabular}

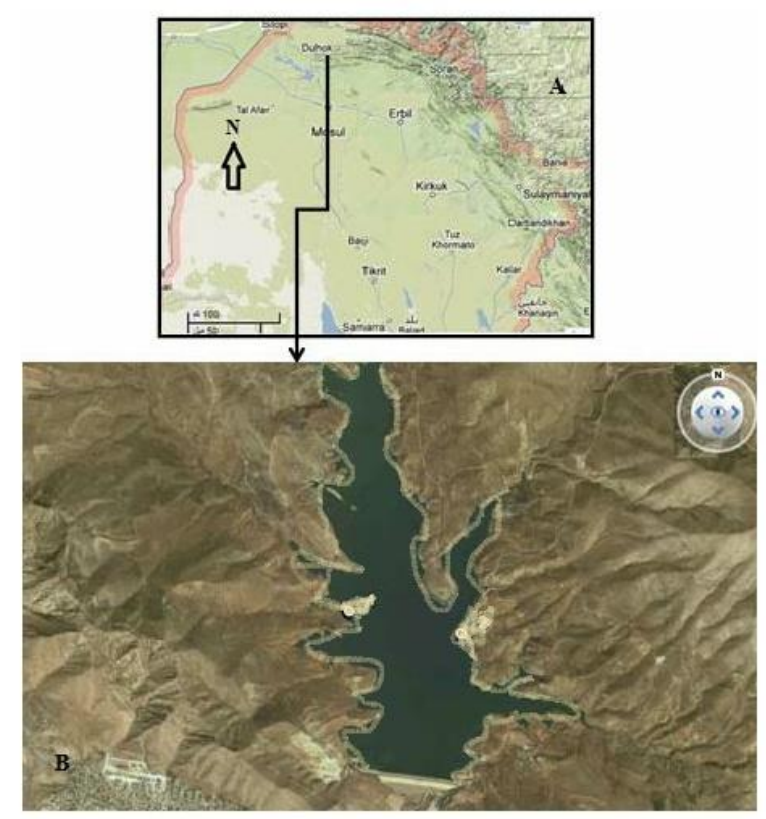

Figure (1):- A- Map of Northern of Iraq show Duhok Lake B-Map of Duhok Lake

\section{Results and discussion}

The information about phytoplankton content of Duhok lake taken from the study carried outin 2002 by( Al- Nakshabandi, 2002). A total of 250 algal flora which have into 7 taxonomic groups were determined was dominated by diatoms $(46 \%)$ followed by Chlorophyta $(24.4 \%)$ then Cyanophyta ( $18.8 \%)$ other divisions were Chrysophyta (3.6\%), Euglenophyta (3.6\%), Pyrophyta (2.4\%) and Charophyta ( $1.2 \%)$ are reprehensive in( figure 2).

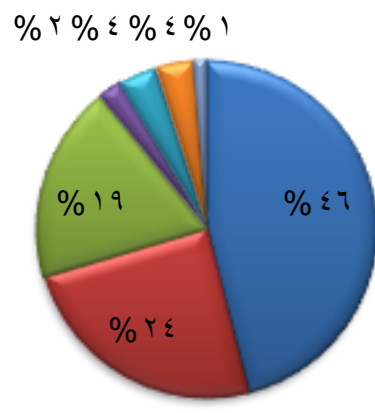

$$
\begin{aligned}
& \text { Bacilario phyta } \\
& \text { Chlorophyta } \\
& \text { Cyanophyta } \\
& \text { Pyrophyta } \\
& \text { Chrysophyta } \\
& \text { Eugleno phyta }
\end{aligned}
$$

Fig. 2:- Phytoplankton species for each division collected from Lake Duhok 2002 
The list of planktonic algae dominant monthly in Lake Duhok is given in Table 4. Looking the species frequently present in mesotrophic and Eutrophic character lakes have been identified in previous study of Duhok lake (Al- Nakshabandi, 2002) .

Table 4. Dominant genius recorded at different months in Lake Duhok Duhok ( 2002)

\begin{tabular}{ll}
\hline Anabaena & Cyclotella \\
Oscillatoria & Synedra \\
Straustarum & Navicula \\
Peridinium & Nitzschia \\
Ceratium & \\
\hline
\end{tabular}

In general, the phytoplankton was numerically dominated by Bacillariophyceae observed in the highest percentage in all stations 46\% in Duhok lake (Al- Nakshabandi, 2002), the domination of diatom is well known phenomenon in Iraqi water and recorded by many researcher (Al-Lami et al, 2000 and Al-Saadi and Ismail,2001), which may be due to the ability of diatom to grow and reproduce in wide range of environmental changes such as temperature, light intensity, nutrients availability and salinity, the composition of algal community quickly respond to changes in physical, chemical and biological factors (Kassim and Mukar, 2006). species of Cyclotella identified in Duhok lake and are more dominant than others species (Al- Nakshabandi, 2002), these species of Cyclotella were tolerance to a wide range of ecological factors such as temperature. Cyclotella species are recognized by many of the researchers as main components of lake that was mesotrophic (Trifonova, 1998and Moss ,1998 ). According to (Round , 1956 ), Cyclotella species are bio-monitor species in transition to eutrophic. Synedra, Nitzschia and Navicula were the most identified genera at all of these studied sites in Duhok lake because of their wide environmental condition tolerance range(Al- Nakshabandi, 2002).

While Chlorophyceae were the subdominant group after Bacillariophyta in the percentage of species numbers following by Cyanophyceae were reached to $24 \%$, and $19 \%$ of the phytoplankton in Duhok lake(Al- Nakshabandi, 2002), this is the regime in the Iraqi water where the Chlorophyceae more than Cyanophyceae in water, which refer, to species exiguities of Cyanophyceae in Tigris and Euphrates basin (Talling,1980 and Al-Nimma,1982).Cyanophyta, especially Anabaena and Oscillatoria was found to be most frequent algae many sites in Duhok lake by (Al- Nakshabandi, 2002). (Fattah, 2010 ; Wu and Suen 1985) concluded that Oscillatoria s p. is found in organic polluted water. Most of algal taxa disappear during rainy season may be due to high water turbidity and suspended solids. Similar conclusion made in Duhok lake by (Al- Nakshabandi, 2002). A mong the Pyrophyta, Ceratium. hirundinella and Peridinium Cinctum . was recorded as dominant in Meso-eutrophic Lake in summer months (Zębek, 2009 ). Ceratium hirundinella and Peridinium cinctum among Pyrophyta are the algae dominant in hot seas on in Duhok Lake(Al- Nakshabandi, 2002) . C. hirundinella is the estimated of mesotrophic waters and they are usually common in the summer in oligotrophic and mesotrophic lakes (Reynolds et al 2002). Another Pyrophyta, Peridinium cinctum has been recorded intensely in the hot months. This species exists in mesotrophic lakes as well (Reynolds et al 2002).Nygaard's indices of various communities of algae Myxophycean, Chlorophycean, Diatoms, Euglenophycean and Compound Quotient (CQ) are used to evaluate of the degree of pollution in the water. The trophic state index of Myxophycean and Chlorophycean in Duhok lake is indicating Eutrophic nature of fresh water. The trophic state indices of Diatoms and Euglenophycean indicate oligotrophic nature of Duhok lake water. The compound index indicates the trophic level of a lake (Nygaard, 1949). If the value is less than 1, the lake is accepted as being oligotrophic, whereas if it is greater than 3 , the lake is accepted as being eutrophic. Compound index value (My xophyceae +Chlorococcales + Centrales diatoms + Euglenales / Des mideae) has been found to be 14.7 for Duhok Lake, indicating that it is eutrophic (Table 5). 
Table 5 :-Nygaard's Trophic Status Indices Duhok lake

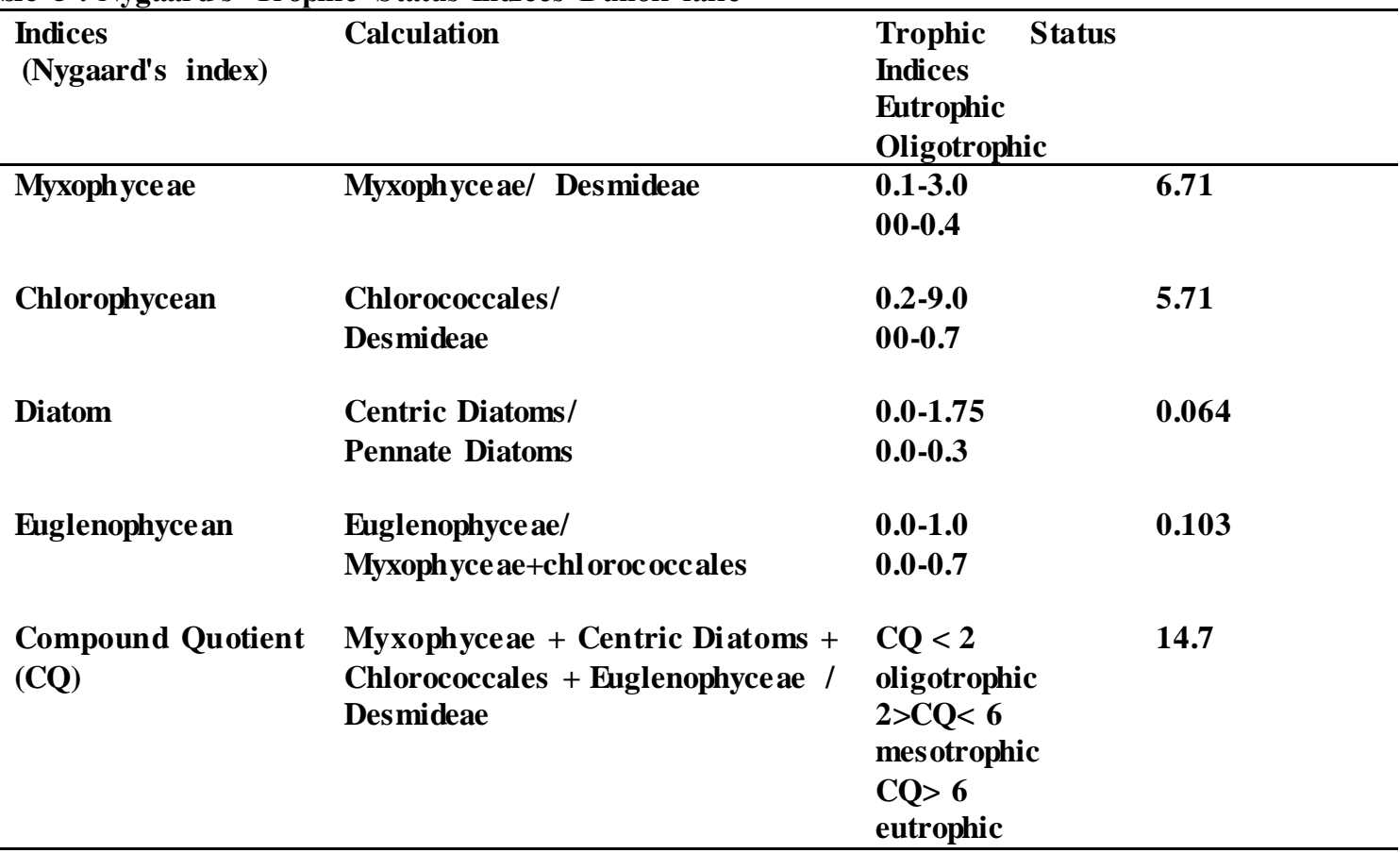

Algal species are good indicators of water quality and change in environment (Patrick, 1948 and Dixit et al,1992 ). Indicator algae are used for detect of water quality and trophic value of water. In this research, the importance species among Duhok Lake planktonic algae which are recorded as dominant were given in( table 6). The water quality and trophic level of Duhok Lake were related to dominant genus scores( Peerapornpisal, et al, 2007). The dominant genus score obtained was 5.7 in Duhok lake during 2002 (table 6). Since this value is included in the range of 5.6-7.5, trophic level of Duhok Lake was "Meso-eutrophic status" and moderate -polluted in 2002 and depending in table(7).

Table 6. Dominant genera and scores in the Duhok Lake during 2002

\begin{tabular}{llll}
\hline Genus & Score & Genus & Score \\
\hline Cyclotella & 2 & Ceratium & 4 \\
Navicula & 5 & Anabaena & 8 \\
Nitiazschia & 9 & Oscillatoria & 9 \\
Synedra sp & 6 & Straustarum & 3 \\
Peridinium & 6 & & \\
dominant genus score $=5.7$ & & \\
Water quality by trophic level is Meso-eutrophic status & \\
General water quality was moderate- polluted &
\end{tabular}

Table 7. Water quality scores followed trophic level and general water quality (Peerapornpisal et al, 2007)

\begin{tabular}{|c|c|c|c|}
\hline & Score & Water quality by trophic level & General water quality \\
\hline $1.0-2.0$ & & Oligotrophic status & Clean \\
\hline $2.1-3.5$ & & Oligo-mesotrophic status & Clean-moder ate \\
\hline $3.6-5.5$ & & Mesotrophic status & Moderate \\
\hline $5.6-7.5$ & & Meso-eutrophic status & Moderate-polluted \\
\hline $7.6-9.0$ & & Eutrophic & Polluted \\
\hline $9.1-10.0$ & & Hypereutrophic status & Very polluted \\
\hline
\end{tabular}


Chlorophyll-a (chl-a) is an important parameter to determine the lake trophic state. It is one major factor affecting water environment, and produces visible changes in the surface of waters (Zhang et al, 2002). Since it exists in all algae groups in marine and freshwater systems, chl-a concentration is a key indicator for bioproduction of inland water body(Zhang et al, 2002). In this survey on the impoundment of Duhok (Al- Nakshabandi, 2000) the chlorophyll a estimation indicated high productivity according to (Vennie ,1999) which was illustrated down below in table (8), and this was evident from the results where the concentration exceeded $15 \mu / \mathrm{L}$ in all sites within the lake and lake was Eutrophic status. This may be attributed to various factors, such as, increasing water temperature, high intensity of incident radiation, in addition to, nutrients input from surrounding agricultural lands (Santos et al, 2014).

Table 8. Trophic boundaries in lakes, as determined from chlorophyll-a mean concentration in lakes ( $\mu \mathrm{g} / \mathrm{L})$ by Vennie (1999)

\begin{tabular}{lc}
\hline Trophic category & Chlorophyll a \\
\hline Oligotrophic & $4 \leq$ \\
Mesotrophic & $4-15$ \\
Eutrophic & $\geq 15$ \\
Chlor ophyll a concentration exceeded $15 \mu \mathrm{g} / \mathrm{L}$ in Duhok \\
lake by (Al- Nakshabandi, 2000 )
\end{tabular}

Algal pollution indices of (Palmer,1969) depended on genus were used in samples of $\mu$ water for high pollution by organic matter. Twenty more frequently genera were taken into account (Table 9). A pollution index factor was used to each genus by assessing the relative number of Total Point Scored by each algae, for explaining of water samples as high or low polluted by organically. A pollution index factor of 1 through 5 has been assigned for each of the 20 kinds of algae that are most tolerant to organic pollution. Kinds of algae most tolerant of organic pollution were used number of 5. Less tolerance types were used a low number. If the pollution index is 20 or more, is explain that was of high organic pollution(Palmer,1969). A number of 15-19 means probable organic pollution. Lower scores usually indicate less organic pollution. In present study, Palmer index was calculated for Duhok lake and it is found that out of 20 Genus, 15 Genus were found with total index value of 37 that means high organic pollution in Duhok Lake and clearly indicated that the water body was eutrophic nature. Detailed results of the Palmer Index are summarized in Table (3).

Table 9 :- Algal Genus Pollution Index (Palmer 1969)

\begin{tabular}{lll}
\hline Genus & Pollution Index & Duhok Lake \\
\hline Anacystis & $\mathbf{1}$ & - \\
Ankistrodesmus & $\mathbf{2}$ & $\mathbf{2}$ \\
Chlamydomonas & $\mathbf{4}$ & $\mathbf{4}$ \\
Chlorella & $\mathbf{3}$ & $\mathbf{3}$ \\
Closterium & $\mathbf{1}$ & $\mathbf{1}$ \\
Cyclotella & $\mathbf{1}$ & $\mathbf{1}$ \\
Euglena & $\mathbf{5}$ & $\mathbf{5}$ \\
Gomphonema & $\mathbf{1}$ & - \\
Lepocinclis & $\mathbf{1}$ & $\mathbf{1}$ \\
Melosira & $\mathbf{1}$ & $\mathbf{1}$ \\
Micractinium & $\mathbf{1}$ & - \\
Navicula & $\mathbf{3}$ & $\mathbf{3}$ \\
Nitzschia & $\mathbf{3}$ & $\mathbf{3}$ \\
Oscillatoria & $\mathbf{5}$ & $\mathbf{5}$ \\
Pandorina & $\mathbf{1}$ & $\mathbf{1}$ \\
Phacus & $\mathbf{2}$ & $\mathbf{2}$ \\
Phormidium & $\mathbf{1}$ & - \\
Scenedesmus & $\mathbf{4}$ & $\mathbf{4}$ \\
Stigeoclonium & $\mathbf{2}$ & - \\
Syndra & $\mathbf{2}$ & $\mathbf{2}$ \\
Palmer Index value & & $\mathbf{3 7}$ \\
\hline
\end{tabular}


Palmer's,(1969) has explain that the genera such as Oscillatoria, Euglena, Scenedesmus, Chlamydomonas, Navicula, Chlorella ,Nitzschia and Ankistrodesmus were found in water polluted by organic matter supported by( Jafari and Gunale, 2006); Sanap, 2007). Similar genera were recorded in the Duhok lake by (Al- Nakshabandi, 2002) . The presence of Oscillatoria, Euglena, Chlorella, Scenedesmus, Gomphonema and Melosira were identified frequently and consider as indicators of pollution in view of the results of Palmer pollution index. Palmer, (1969), the genus Euglena tops the list of his sixty most tolerant genera of pollution.

Patrick,( 1965) concluded that Euglena and Oscillatoria are highly pollution tolerant genera and therefore, reliable indicators of Eutrophication. Palmer, (1969) suggested that algae are reliable indicators of polluted water as it was true in present study.

\section{Conclusions}

Nygaard's indices of various communities of algae Myxophycean, Chlorophycean, Diatoms, Euglenophycean and compounds were used to evaluate of the trophic state of this lake. All the indices were showing eutrophic nature of the sites except diatoms and Euglenophyceae indices. The compound index which had the widest range and was very sensitive holds good index for assessing the eutrophication of the lake. According to dominant genus Scores Lake was mesotrophic-eutrophic character according to trophic level in addition, the water quality of Lake Duhok was moderate and moderate polluted .Chlorophyll a concentration shows the Duhok lake was Eutrophic. By using Palmer's pollution index number, the total score of Duhok Lake was 37 indicating the confirmed high organic pollution. Thus the pollution tolerant algal communities can be used as bio-indicators of organic pollution.

\section{References}

Al- Nakshabandi, I. Z. R. 2002. A Phycological study on Duhok impoundment its main watershed. Ph.D. Dissertation- Duhok University-Iraq. 143pp.

Al-Lami, A. A ; Kassim ,T. I. and Salman , S. K..2000. "Phyto-plankton of Tigris River, Iraq," 1 st National Scientific Conference in Environmental Pollution and Means of Protection, Baghdad, 5-6 November, pp. 10-20.

Al-Nimma, B. A. 1982“A Study on the Limnology of the Tigris and Euphrates Rivers," M.Sc. Thesis, University of Salahaddin, .

Al-Saadi , H. A. and Is mail, A. M. 2001."Comparison of Phyto-plankton Composition in Artificial Lake and Tigris River, Middle of Iraq," Journal of College Education for Women, University of Baghdad, Vol. 12, No. 1, pp. 105- 112.

Bhatt, L.R ; Lacoul, P ; Lekhal, H.D and Jha, P.K.(1999). Physico-chemical characteristics and phytoplankton's for Taudha Lake, Kathmandu. Pollution Research, 18, 353-358.

Chandrashekar, C., K.V. Lokesh, H. Pushpa and G. Ranganna.( 2014). Studies on the assessment of trophic status of Lakes. Inter. J. of Current Microbio. and. Appl. Sci. 3(6): 245-254.

Fattah, A.O.2010. "Phyco-limnological study on Khabour River". M.Sc. Thesis. University of DuhokDuhok, Iraq.

Henderson-sellers, B. and H. R. Markland 1988. The origins and control of cultural eutrophication. New York 294pp.

Hutchinson, G.E. A.1967. Treatise on limnology, 2nd ed., Introduction to lake biology and the limn plankton, New York.

Jafari, N. G. \& Gunale, V.R. (2006):Hydrobiological Study of Algae of an Urban Freshwater River. Journal of Applied Science of Environmental Management,10(2): 153-158.

Johson, R.W and Harris, R.C.1980. Remote sensing for water quality and biological measurements in coastal waters. Photogramm. Eng. Remote Sens. 1980, 46, 77-85.

Kassim , M. and Mukai , H.2006 "Contribution of Benthic and Epiphytic Diatoms to Clam and Oyster Production in the Akkeshi-Ko Estuary," Journal of Oceanography, Vol. 62, pp. 267-281. doi:10.1007/s 10872-006-0051-9.

Moss B.1998. Ecology of freshwater: man and medium, past to future. Blackwell Science Ltd, Oxford. Nygaard G.1949. Hydrobiolog ical studies on some Danish ponds and lakes. Part 2. The quotient hypothesis and some new or little known phytoplankton organisms. Det Kong Danske Vidensk Selskab, Biol Skr 1949;7:1-293. 
Nygaard, G. 1976. Talverne fra Dansk Phytoplankton. Gyledondal.125pp.

Palmer, C.M.(1969). Composite rating of algae tolerating organic pollution. J. phycol. 5: 78-82.

Patrick, R. (1965): Algae as indicator of pollution: An biological problem in water pollution 3rd seminar Third seminar 1962. Robt. A. Taft. Sanitary Engineering Center, Publ. Hlth. Serv. Publs. Wash. 223-232.

Peerapornpisal, Y ; Pekkoh, J ; Powangprasit, D ; Tonkhamdee, T ; Hongsirichat, A and Kunpradid T.2007. Assessment of water quality in standing water by using dominant phytoplankton (AARL-PP Score). J Fish Technol Resh 2007;1:71-81.

Plafkin, J.L.; Barbour, K.D ; Porter, S.K ; Gross. R.M. \& Hughes (1989). Rapid Assessment Protocols for Use in Streams \& Rivers: Benthic Macro invertebrates \& Fish. EPA:Washington, Chap man \&Hall: New York, NY.

Reynolds C.S ; Huszar, V; Kruk, C ; Naselli-Flores, L and Melo, S.2002. Review towards a functional classification of the freshwater phytoplankton. J Plankton Res .24:417-428.

Round ,F.E. 1956.The phytoplankton of three water supply reservoirs in Central Wales. Arc F Hydrobiology 1956;52:457-469.

Sanap, R.R. (2007): Hydrobiological studies of Godavari River up to Nandur-Madhmeshwar dam, DistNashik, Maharashtra. Ph. D. thesis, University of Pune, Pune, India.

Santos, J. C. N.; Andrade, E. M.; Neto, J. R. A. ; Meireles, A. C. M. and Palacio, H. A. Q. 2014. Land use and trophic state dynamics in a tropical semi- arid reservoir. Revista Ciencia Agrondmica. 45(1):35- 44

Scherz, J.P.1972. Development of a Practical Remote Sensing Water Quality Monitoring System. In Proceeding of 8th International Sy mposium on Remote Sensing of Environment, University of Michigan, Ann Arbor, MI, USA, 2-6 October.

Shekha Y. A., H. M. Ismael and A. A. Ahmed. 2013. Bacteriological and mycological assessment for water quality of Duhok Reservoir. Jordan J. of Biol. Sci. (JJBS). 6(4):1-10.

Talling. F.1980. "Euphrates and Tigris, Mesopotamian Ecol-ogy and Desting," Vol. 38, The Hyge-BostonLondon. pp. 63-86.

Thunmark, S. 1945. Zur sociologic des susswasser planktons. Eine methodologisch-okologische studie. .Folia Limnologica Scandinavica, 3.

Trifonova, I.S.1998. Phytoplankton composition and biomass structure in relation to trophic gradient in some temperate and subarctic lakes of north-western Russia and the Prebaltic. Hydrobiology $.369 / 370: 99-108$.

Vennie, J.(1999). Understanding Lake Data. Wisconsin. Department of Natural Resources, Bureau of Fisheries Managements and Habitat Protection.

Wu, J. T. and Suen, W. C.1985. "Change of Algal Association in Relation to Water Pollution". Botanical Bulletin Academia Sinica. Vol. 26, pp. 203-212.

Zębek ,E.2009. Seasonal changes in net phytoplankton in two lakes with differing morphometry and trophic status (northeast Poland). Arch. Pol. Fish 2009;17:267-278.

Zhang, Y;, Koponen, S; Pulliainen, J \& Hallikainen, M. (2002). Application of an empirical neural network to surface water quality estimation in the Gulf of Fin land using combined optical data and microwave data. Remote Sensing of Environment, 81(2-3), 327-336. 